PELEH3II

DOI https://doi.org/10.32838/TNU-2707-0581/2020.5/22

Головкін Б.М.

Національний юридичний університет імені Ярослава Мудрого

\title{
РЕЦЕНЗІЯ НА МОНОГРАФІЮ А.В. БОРОВИКА TA О.Г. КОЛБА «PRE-TRIAL INVESTIGATION OF CRIMES COMMITTED IN THE PLACES OF IMPRISONMENT» («ДОСУДОВЕ РОЗСЛІДУВАННЯ ЗЛОЧИНІВ, ВЧИНЕНИХ У ВИПРАВНИХ КОЛОНІЯХ»)
}

Результати грунтовного вивчення змісту рецензованої роботи кандидата юридичних наук, доцента Боровика Андрія Володимировича, та доктора юридичних наук, професора Колба Олександра Григоровича, «Pre-trial investigation of crimes committed in the places of imprisonment» показали, що це дослідження є досить актуальним та таким, що має теоретичне та практичне значення.

Як свідчить практика боротьби із злочинністю, зокрема й у місцях позбавлення волі, іiі ефективність, у першу чергу, зумовлена змістом відповідної політики та ії реалізацією на нормативно-правовому рівні.

В ідеалі політика у сфері боротьби із злочинністю, як і будь-який інший вид політики держави, повинна здійснюватися на підставі розробленої концепції, являти собою відповідну політичну лінію - політику у сфері боротьби зі злочинністю.

При цьому залежно від часу та законодавства така політика може набувати різних ознак, як от: кримінальних, кримінально-процесуальних тощо.

Звичайно, що виділення вказаних напрямів правової політики боротьби із злочинністю $є$ дещо умовним, оскільки ця державна політика реально становить собою, як правило, комплексне вирішення і соціальних, і правових завдань боротьби зі злочинністю, всі складники якої знаходяться (повинні знаходитись) між собою у функціональній залежності і взаємодії.

Досягнення необхідного для суспільства стану безпеки від злочинних посягань можливе лише шляхом широкого й комплексного поєднання заходів боротьби зі злочинністю: організаційноправових i адміністративно-управлінських (як

${ }^{1}$ Borovyk A.V., Kolb O.H. Pre-trial investigation of crimes committed in the places of imprisonment: monograph. Riga : Baltija Publishing, 2020. 304 p. прояв державної волі); соціально-економічних, культурологічних та природно-людських (як розвиток суспільства та людини); спеціально-законодавчих, методологічно-правових і кримінологічних як взагалі, так і певними іiї видами. У межах цих заходів кримінально-правовий напрям державної політики у сфері боротьби зі злочинністю виконує функцію системо утворюючого елемента і $\epsilon$ необхідним інструментом досягнення суспільно-корисного результату.

Зазначені теоретико-прикладні засади й були використані у цій монографії під час з'ясування змісту реалізації сучасної кримінально-процесуальної політики в контексті вирішення проблем, пов'язаних із розслідуванням та розкриттям злочинів, учинених засудженими у виправних колоніях України. При цьому був застосований відомий у науці підхід, відповідно до якого всі види політики, включаючи кримінально-процесуальну, реалізуються у формі законодавства та юридичної практики (зокрема, шляхом так званого правового регулювання суспільних відносин).

Саме тому злочинності, включаючи у виправних колоніях, можна протидіяти лише із застосуванням теоретично напрацьованих засад щодо розуміння іiі змісту, а також форм і методів реалізації усіх видів політики у сфері боротьби із злочинністю у законодавчих актах та на практиці, запобігання i протидії суспільно небезпечним діянням, що посягають на всі суспільні відносини у цілому.

Зазначені теоретичні підходи, а також проблеми досудового розслідування кримінальних правопорушень, учинених у виправних колоніях, мова про які ведеться у всіх розділах цієї монографії, й зумовили вибір предмету даного дослі- 
дження, а також його доктринальне та прикладне значення.

Особливу цінність роботи складає те, що вона написана на іноземній «англійській» мові та видана у країні Свропейського Союзу, а саме - в Ризі (Латвійська Республіка), що дасть можливість ознайомитися із працею науковцям за межами України.

Монографія кандидата юридичних наук, доцента Боровика Андрія Володимировича, та доктора юридичних наук, професора Колба Олександра Григоровича, "Pre-trial investigation of crimes committed in the places of imprisonment" (Досудове розслідування злочинів, вчинених у виправних колоніях) повною мірою відповідає вимогам МОН України, що пред'являються до такого виду навчально-методичних видань, та має практичне та теоретичне значення для подальших наукових розробок як в Україні, так і за кордоном. 